Research Article

\title{
Development of Kaolin Clay as a Cost-Effective Technology for Defluoridation of Groundwater
}

\author{
Adane Adugna Ayalew (i) \\ Faculty of Chemical and Food Engineering, Bahir Dar Institute of Technology, Bahir Dar University, Bahir Dar, Ethiopia \\ Correspondence should be addressed to Adane Adugna Ayalew; adaneadugna14@gmail.com
}

Received 14 May 2020; Revised 30 July 2020; Accepted 21 September 2020; Published 7 October 2020

Academic Editor: Maksim Mezhericher

Copyright (C) 2020 Adane Adugna Ayalew. This is an open access article distributed under the Creative Commons Attribution License, which permits unrestricted use, distribution, and reproduction in any medium, provided the original work is properly cited.

\begin{abstract}
Excessive fluoride in potable groundwater is a serious health problem in rural areas of many developing countries. The presence of a small amount of fluoride in potable water is beneficial to human health, but a high amount $(>1.5 \mathrm{mg} / \mathrm{L})$ has adverse effects. The present study is aimed to prepare a new cost-effective adsorbent of kaolin clay that can be used as a valuable defluoridating agent. Characterization of the prepared adsorbent was carried out using DSC, FTIR, TGA, and XRD. Also, the surface area of the adsorbent was measured by BET analysis. The clay was activated with concentrated $\mathrm{H}_{2} \mathrm{SO}_{4}$, and the effects of various experimental parameters such as temperature $\left(25,40,50\right.$, and $\left.60^{\circ} \mathrm{C}\right), \mathrm{pH}(2,4,6$, and 8$)$, particle size $(<0.075,0.075-0.15$, and $0.15-0.30 \mathrm{~mm})$, contact time $(30,60,90,120$, and $150 \mathrm{~min})$, and dose of the adsorbents $(0.5,1,1.5,2.0$, and $2.5 \mathrm{~g})$ were investigated using a batch adsorption method. The specific surface area of raw and activated clay was found to be $10.598 \mathrm{~m}^{2} / \mathrm{g}$ and $5.258 \mathrm{~m}^{2} / \mathrm{g}$, respectively. The optimum fluoride removal by both adsorbents was obtained at $\mathrm{pH} 4$, temperature $50^{\circ} \mathrm{C}$, particle size $0.075 \mathrm{~mm}$, and $60 \mathrm{~min}$. In both adsorbents, the degree of fluoride removal was increased with a decrease in the particle size of the adsorbent and increased contact time and dosage of the adsorbent. In all parameters, adsorption by activated clay was better than raw kaolin clay for retaining fluoride. The obtained data were well fitted with Freundlich and Langmuir isotherm models.
\end{abstract}

\section{Introduction}

Nowadays, technology is playing a major role in energy, environment, and green technology environment [1-10]. Fluoride ion exists in natural waters, and it is a vital micronutrient in humans in avoiding dental caries and in facilitating the mineralization of hard tissues, if taken at a suggested range of concentration [11]. The World Health Organization (WHO) has established a guideline of $1.5 \mathrm{mg} / \mathrm{L}$ for fluoride in drinkable water [12]. Higher concentration than this rate can cause fluorosis (dental and skeletal) and numerous types of neurological harm in harsh cases, such as cancer, damage kidney, liver, nervous systems, thyroids, respiratory problems, Alzheimer, and reduce pregnancy [13].

The incident of high fluoride concentrations in underground water and the risk of fluorosis allied with using such water for human consumption are troubles faced by many developing countries, particularly Rift Valley countries such as Ethiopia [14]. Ethiopia is the most impacted nation in Africa by the fluoride problem. In Ethiopia, the concentration of fluoride in the potable water sources has been reported above $33 \mathrm{mg} / \mathrm{L}$ [15]. Based on the Ministry of Energy and Water of Ethiopia, the supply of drinking water in the rural Rift Valley region depends on groundwater $[16,17]$. Presently, many people are used to drinking water from bore wells in the Rift Valley, and fluorosis becomes a serious health problem $[18,19]$.

There are several fluoride removal techniques reported in the literature including chemical precipitation [9], membrane processes, reverse osmosis [20,21], adsorption $[22,23]$, ion exchange, and electrocoagulation [24, 25]. However, the use of these techniques is limited by high operational cost and ineffective removal efficiency. Adsorption is predicted as the most effective, capable, and widely used crucial method in the water and wastewater treatment processes [26]. 
Different types of adsorbent materials such as activated carbon [27], clay [28], fluorspar and quartz [29], fly ash [30], kaolinite [31], bone char [32], red mud [33], and bentonite [34] have been employed to find out which one is economically feasible for defluoridation. Kaolin clay and clay minerals are naturally plentiful, renewable, and environmentally sustainable [35-37]. They are considered as strong adsorbents [38] due to their low cost, sorption properties, and ion exchange perspective.

Clay is a simple sedimentary material composed mostly of fine particles of hydrous aluminium silicates and other minerals and impurities [39]. Both clay powder and fired clay are capable of sorption of fluoride as well as other pollutants from water. The ability of clay to clarify turbid water is well known. This property is believed to have been known and utilized at the domestic level in ancient times [38]. The present study intends to remove fluoride from groundwater using economically effective and locally available kaolinite clay adsorbents. Raw clay and acid-treated kaolinite clay have been characterized using DSC, FTIR, TGA, and XRD. Also, the surface area of the adsorbent was measured by BET analysis. The effects of operating parameters such as temperature, $\mathrm{pH}$, particle size, time, and adsorbent dosage were studied in a batch adsorption experiment. Adsorption isotherms were also studied.

\section{Materials and Methods}

2.1. Materials and Chemicals. Natural kaolin clay was collected from the local area, Debre Tabor town, specifically Gasay in the Amhara Region, Ethiopia. All laboratory grade reagents such as sodium hydroxide $(\mathrm{NaOH})$, distilled water, liquid nitrogen, and sulfuric acid $\left(\mathrm{H}_{2} \mathrm{SO}_{4}\right)$ were used without any purification.

2.2. Preparation of Adsorbents. The raw kaolin clay was benficiated in order to remove and purify kaolin from other combined impurities such as soluble salts, metallic oxides, and impurities (pebbles and quartz) from the clay. The beneficiated clay was dried at $105^{\circ} \mathrm{C}$ for $2 \mathrm{~h}$. After effective drying, it was crushed by using a jaw crusher and then sieved through $<0.075,0.075-0.15$, and $0.15-0.3 \mathrm{~mm}$ sieve sizes. The powder of clay was calcined at $750^{\circ} \mathrm{C}$ for $2 \mathrm{~h}$ using the muffle furnace (Nabertherm B180) for processing into metakaolin and then was cooled for $1 \mathrm{~h}$. The essence of this is to dehydroxylate the beneficiated kaolin to form an activated amorphous material called metakaolin. Furthermore, metakaolin was activated by using $2 \mathrm{M}$ of $\mathrm{H}_{2} \mathrm{SO}_{4}$ for $12 \mathrm{~h}$ at room temperature to split into silica and alumina components. Then, the sample was washed continuously with distilled water to remove acid and made it to neutralize. After all, the sample was dried at $105^{\circ} \mathrm{C}$ for $12 \mathrm{~h}$ in the oven, and finally, samples were kept in a desiccator for further analysis.

2.3. Preparation of Fluoride Concentration. The solution of fluoride was prepared using distilled water by diluting the prepared stock solution $(100 \mathrm{mg} / \mathrm{L})$ to preferred concentration. Sodium fluoride $(\mathrm{NaF})$ with a purity of $97 \%$ was used as a source of stock solution. The known fluoride concentrations were prepared, and their absorbency values were measured from the UV/VIS spectrometer.

2.4. Experimental Design and Descriptions. A measured amount of the fluoride tap water sample $(100 \mathrm{~mL})$ was taken in a $250 \mathrm{~mL}$ conical flask for the batch experiment. In the conical flask, calculated amount of the adsorbent powder was added and stirred with a magnetic stirrer on a hot plate at $300 \mathrm{rpm}$. The batch adsorption experiment was performed for a wide range of temperature $\left(25,40,50\right.$, and $\left.60^{\circ} \mathrm{C}\right)$, contact time $(30,60,90,120$, and $150 \mathrm{~min})$, solution $\mathrm{pH}(2,4$, 6 , and 8$)$, particle size $(<0.075,0.075-0.15$, and $0.15-0.3 \mathrm{~mm})$, and adsorbent dosage $(0.5,1,1.5,2$, and $2.5 \mathrm{~g})$. At the closing stages of each test, a little amount of the solution was taken at a fixed time, and the residue was filtered. After the adsorption experiment, the absorbency value of the solution was measured. The final fluoride concentration was calculated from the calibration curve. The percentage of removal of fluoride was calculated by equation (1), and the equilibrium state concentration of fluoride adsorbate in the solid phase (Qe, $\mathrm{mg} / \mathrm{g}$ ) was determined by equation (2):

$$
\begin{aligned}
(\%) \text { adsorption } & =\frac{\mathrm{Co}-\mathrm{Ce}}{\mathrm{Co}} * 100, \\
\text { adsorption capacity }(\mathrm{Qe}) & =\frac{(\mathrm{Co}-\mathrm{Ce}) \mathrm{V}}{\mathrm{M}},
\end{aligned}
$$

where Co is the initial fluoride concentration $(\mathrm{mg} / \mathrm{L}), \mathrm{Ce}$ is the residual fluoride concentration in the liquid phase at equilibrium $(\mathrm{mg} / \mathrm{L}), m$ is the amount of the adsorbent $(g)$, and $v$ is the volume of the solution $(L)$.

2.5. Analysis and Characterization. The absorbency value of the fluoride concentration was analyzed using a UV/VIS spectrometer (Lambda 35 Ferkin Elmer) at wavelength $620 \mathrm{~nm}$ after scanning of fluoride solution [40]. The specific surface areas of raw and activated adsorbents were analyzed by the Brunauer-Emmett-Teller (BET) model NOVA $4000 \mathrm{e}$ analyzer. Fourier-transform infrared (FTIR) spectra were found in the range of $400-4000 \mathrm{~cm}^{-1}$ to examine the major functional group present in kaolin clay and the percentage of transmittance by using JASCO model 4100 before and after adsorption for both adsorbents. The quantitative and qualitative characterization of phases, crystalline, and the number of amorphous phases present were characterized by using an X-ray diffractometer (Min 3740) by a continuous scanning axis of $2 \theta$ with a scan range of $10-80^{\circ}$. Thermal property and mass loss of the kaolin adsorbent were analyzed by thermogravimetric analyzer (SDT Q600) with liquid nitrogen from a temperature of 20 to $1000^{\circ} \mathrm{C}$.

\section{Results and Discussion}

3.1. Characterization of Kaolin Adsorbents. In this study, kaolin adsorbents were characterized based on surface 
functional groups, textural surface area, thermal stability, and crystallite. The effect of operational conditions such as contact time, temperature, solution $\mathrm{pH}$, adsorbent dosage, and particle size was also studied in the batch experiment.

3.2. FTIR Analysis. The major functional group present in kaolin was revealed by the FTIR analysis, FTIR on four samples was analyzed, and these are raw kaolin (before and after adsorption) and activated kaolin (before and after adsorption). Both samples illustrate the same major picks, but their transmittance percentage intensity showed a broad range of difference as presented in Figures 1(a) and 1(b). The absorption bands observed at $3481 \mathrm{~cm}^{-1}$ and $1659 \mathrm{~cm}^{-1}$ could be corresponding to the $\mathrm{OH}$ vibration mode of the hydroxyl molecule, and the bands between 3450 and $3670 \mathrm{~cm}^{-1}$ are attributed to the $\mathrm{OH}$ stretching mode. In the $1000 \mathrm{~cm}^{-1}$ and $500 \mathrm{~cm}^{-1}$ region, the main functional groups were $\mathrm{Si}-\mathrm{O}$ and $\mathrm{Al}-\mathrm{OH}$. The region at $780-798 \mathrm{~cm}^{-1}$ is due to Si-O-Si intertetrahedral bridging bonds in $\mathrm{SiO}_{2}$ and $\mathrm{OH}$ deformation band. When comparing the adsorbents, activated kaolin showed the lowest pick due to the replacement of the fluoride ion on the active surface of the adsorbent. It can also be observed that the bending shape of the adsorbent before adsorption has a high transmittance value than after adsorption. This attributes due to the occupation of all active site adsorbates by fluoride molecules after adsorption. The obtained results ensure that the surface of adsorbents was occupied by fluoride molecules, and due to this, transmittance has been decreased after adsorption. This is because the number of ions adsorbed is high on the adsorbent surface, and the ability of light to transfer through the surface of the adsorbent is low [41].

3.3. Surface Area Analysis. The BET was performed on activated and raw kaolin clay to evaluate the surface area. The BET result presented in Table 1 shows that smaller particle sizes had larger surface areas. Activation of kaolin clay has tended to increase the surface area of the adsorbent through removing the volatiles or impurity from the surface of the adsorbent. To develop high surface area and porosity of the adsorbent to maximize adsorption efficiency, the material needs to be carbonized at low temperature followed by chemical activation [42]. It has been notified from the result that the surface area for both raw and activated adsorbents is higher as compared to the surface area of $10.598 \mathrm{~m}^{2} / \mathrm{g}$ (activated clay) and $5.258 \mathrm{~m}^{2} / \mathrm{g}$ (raw clay) result reported by Srinivasan [43] at less than $0.075 \mathrm{~mm}$ particle size.

3.4. Thermogravimetric Analysis of Kaolin Clay. Differential scanning calorimetry (DSC) and thermogravimetry analysis (TGA) have been used to study the thermal effects during the fluoride ion adsorption process. The dependence on water absorption has been studied with the kaolin clay powder. Studying the thermal property of kaolin clay by using thermogravimetry analysis is important to know the temperature resistance of silicon, aluminum, and other complex functional groups [44]. Thermal property and mass loss of the kaolin clay adsorbent were analyzed by thermogravimetric analyzer (SDT Q600) with liquid nitrogen from a temperature of 20 to $1000^{\circ} \mathrm{C}$. The result is presented in Figure 2. It has been showed that activated kaolin clay was found to be structurally stable from 300 to $750^{\circ} \mathrm{C}$, and above this temperature, a new spinal-like phase was formed. From this, it can be decided that activated kaolin clay can be used for the removal of fluoride from groundwater. A large release of volatile matter and moisture content were observed concurrent with weight loss and endothermic reaction in the TGA value. The intensive mass loss is observed from $75^{\circ} \mathrm{C}$ to $200^{\circ} \mathrm{C}$, which corresponds to removal of surface moisture, and from $300^{\circ} \mathrm{C}$ to $430^{\circ} \mathrm{C}$, slight mass loss has been observed which represents volatile matter and removal of the interior.

3.5. X-Ray Diffraction (XRD) Analysis. XRD stated the structural faults in kaolin because of variability in the peak situation and inflection of their intensity in the kaolin XRD pattern. XRD identification of order and disorder is interesting because of overlapping peaks and boundaries in kaolinite. Activated kaolinite prepared has three main intensity diffraction peaks at $2 \theta$ values of $19.075^{\circ}, 32^{\circ}$, and $33.5^{\circ}$, and also, less intensity result has been observed at $2 \theta$ $67.6^{\circ}, 61^{\circ}, 18.7^{\circ}, 49.5^{\circ}$, and $78.8^{\circ}$. The activated kaolin clay notifies some amorphous structures at some diffraction peaks. At $2 \theta$ values of $21^{\circ}, 24.1^{\circ}, 15.12^{\circ}$, and $27.2^{\circ}$, an amorphous structure is observed as displayed in Figure 3. The XRD pattern also shows that the peak which lies in the range of $20-30^{\circ}$ is indicative of the degree of crystalline which is a basic property for the adsorption process. This designated that most of activated kaolin clays were crystalline which enhances the removal capacity of the fluoride ion on the surface of the adsorbent.

\subsection{Effects of Operating Parameters}

3.6.1. Effect of Temperature. The temperature dependence of fluoride adsorption by raw clay and activated kaolin clay was intentioned with the range of $25-60^{\circ} \mathrm{C}$ at $\mathrm{pH} 4$, fluoride concentration $25 \mathrm{mg} / \mathrm{L}$, and at less than $0.075 \mathrm{~mm}$ particle size. The percentage of adsorption of the fluoride ion at $1 \mathrm{~h}$ contact was found to be $42.3,50.2,56.4$, and $55.53 \%$ for raw clay and 57.2, 61.27, 68.2, and $67.02 \%$ for activated clay, respectively. The graph of the temperature against fluoride adsorbed by the material at four different temperatures is presented in Figure 4. It has been shown that the increase in the percentage of fluoride removal at higher temperatures confirms that the process is endothermic. This is because at higher temperatures, the interface between the fluoride ion and the adsorbent increased with the temperature. The first stage $\left(25^{\circ} \mathrm{C}-40^{\circ} \mathrm{C}\right)$ of the adsorption process corresponds to external surface adsorption or instantaneous adsorption stage. The second stage is that when the temperature increases $\left(40^{\circ} \mathrm{C}-50^{\circ} \mathrm{C}\right)$, the adsorption stage gradually increases. In this model, the clay mineral is treated as being surrounded by a boundary layer film of water molecules through which the fluoride ion must be diffused before 


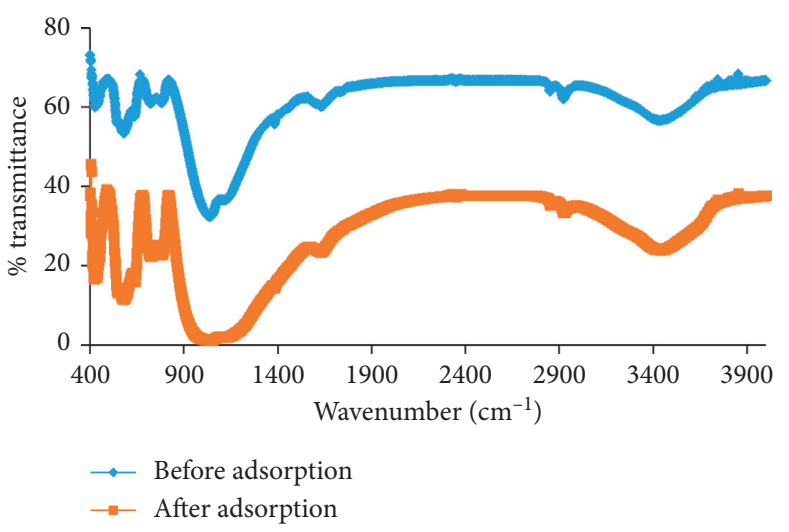

(a)

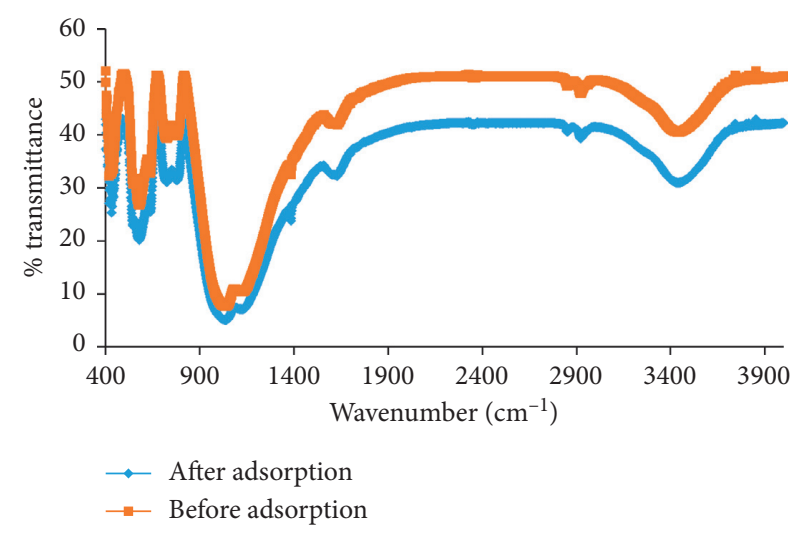

(b)

FIGURE 1: FTIR result of (a) activated kaolin and (b) raw kaolin before and after adsorption of fluoride.

TABLE 1: Summary of BET surface area results of different particle sizes of adsorbents.

\begin{tabular}{lcc}
\hline Particle size $(\mathrm{mm})$ & Surface area of activated clay $\left(\mathrm{m}^{2} / \mathrm{g}\right)$ & Surface area of raw clay $\left(\mathrm{m}^{2} / \mathrm{g}\right)$ \\
\hline$<0.075$ & 10.598 & 5.258 \\
$0.075-0.15$ & 7.498 & 3.312 \\
$0.15-0.30$ & 7.396 & 2.504 \\
\hline
\end{tabular}

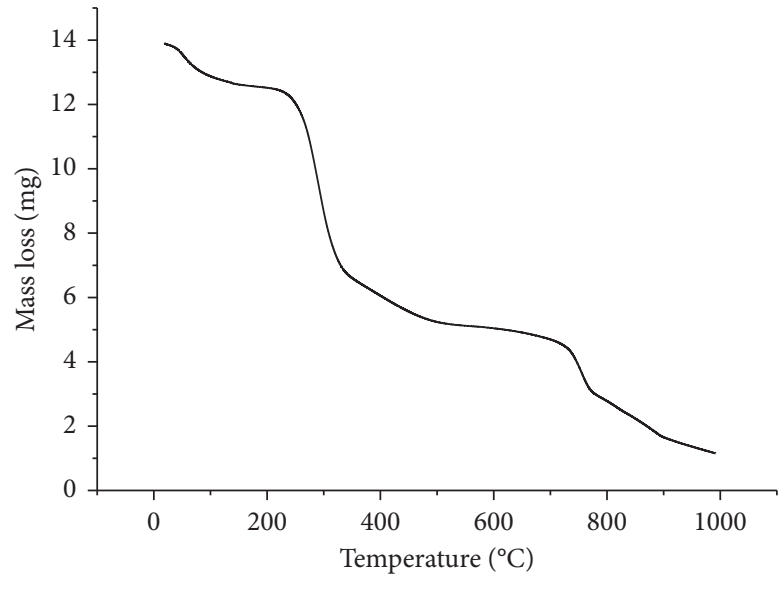

- TGA

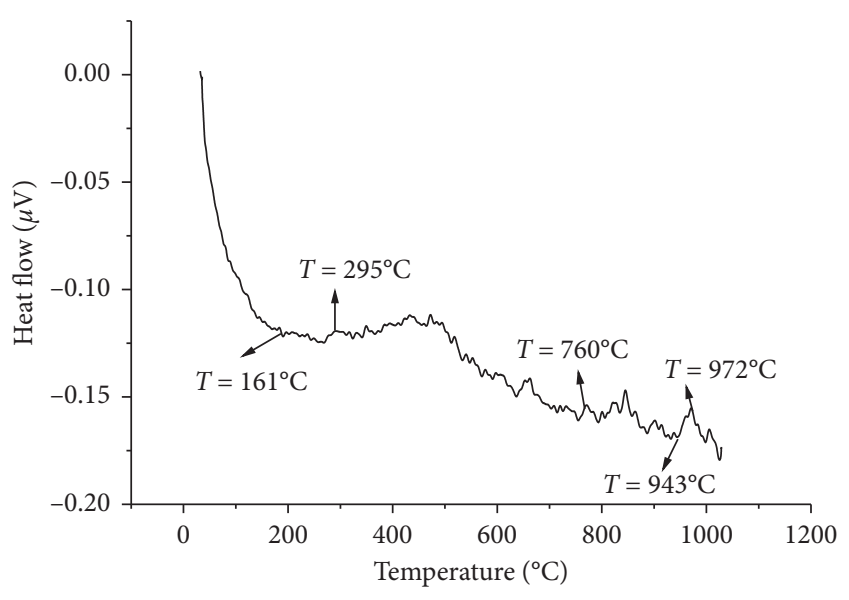

- DSC

(a)

(b)

FIGURE 2: Thermogravimetric analysis of the kaolin clay adsorbent.

adsorption on the clay surface. The subsequent segment amount indicates primarily intraparticle dispersion. The dispersion transport of fluoride occurs through the inner pores of the adsorbent. The third location of the curve shows $\left(50^{\circ} \mathrm{C}-60^{\circ} \mathrm{C}\right)$ the decline in the rate of diffusion getting an equilibrium stage. The inspection about the enhanced fluoride adsorption rate by the adsorbent at higher temperature is in perfect agreement with the earlier finding $[36,38,39]$.

3.6.2. Effect of $p H$. The effect of $\mathrm{pH}$ for removal of fluoride by raw kaolin and activated kaolin clay adsorbents was studied at $\mathrm{pH}$ of $2,4,6$, and 8 . Other parameters were fixed; the temperature was $50^{\circ} \mathrm{C}$, the particle size was $\leq 0.075 \mathrm{~mm}$, the dose was $1 \mathrm{~g}$, and the contact time was $1 \mathrm{~h}$. As shown in Figure 5, when initial pH of solution increased from 2 to 4 , the percentage of removal of fluoride increased from 45.9 to $56.4 \%$ and 57.2 to $68.2 \%$ for raw kaolin clay and activated kaolin clay, respectively. However, as solution $\mathrm{pH}$ increased from 4 to 8 , the percentage of fluoride removal decreased from 56.4 to $30.4 \%$ and 68.2 to $41.06 \%$ for raw kaolin clay and activated kaolin clay, respectively. This is because the clay contains $\mathrm{Al}_{2} \mathrm{O}_{3}$ which acts as an anion on the active site of the adsorbent. Increasing the $\mathrm{pH}$ value leads to an increase in the number of negatively charged sites (the hydroxyl ions, $\mathrm{OH}^{-}$) on the adsorbent; as a result, the percentage of fluoride removal decreased. This is in all probability due to the 


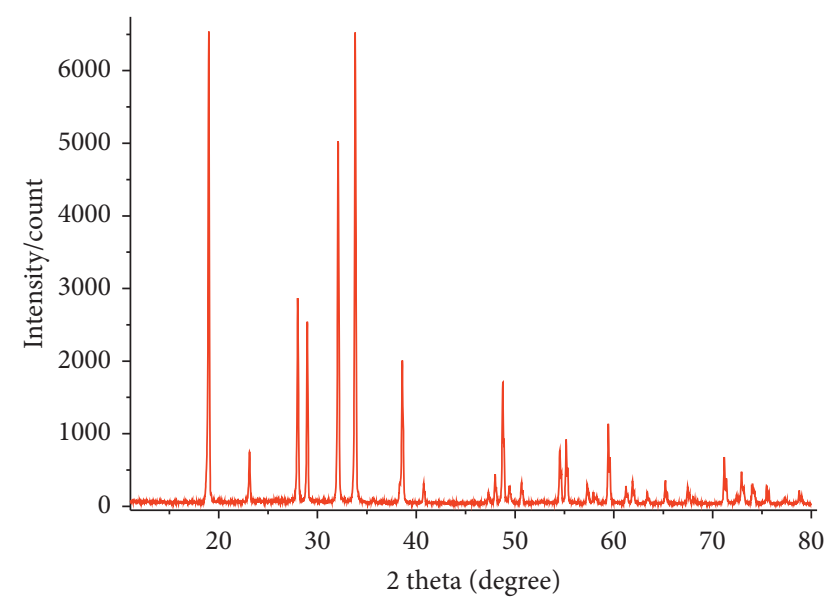

FIGURE 3: XRD patterns of activated kaolin clay.

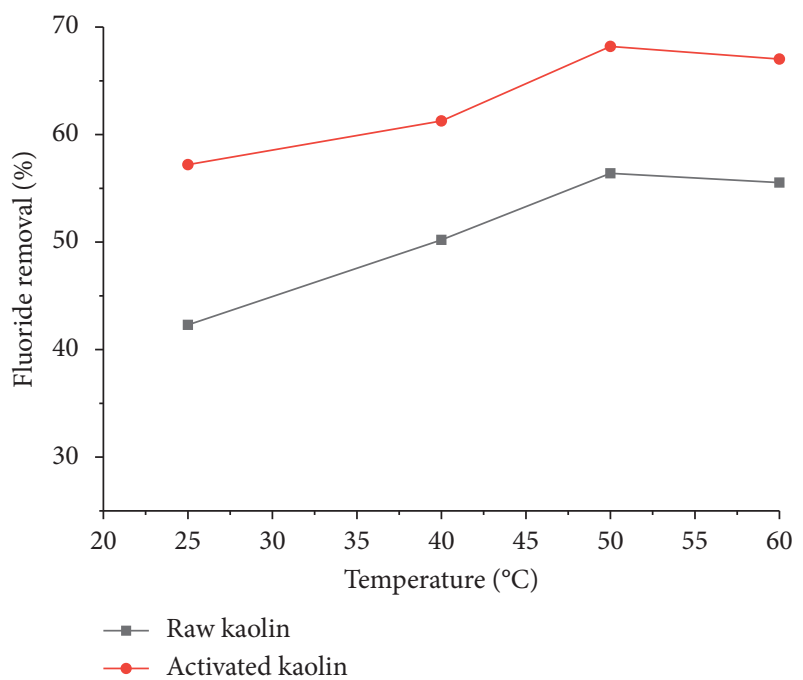

FIgURE 4: Effects of temperature on fluoride removal.

competition for adsorption sites between fluoride and hydroxyl ions at the clay surface. These effects provide more support to earlier findings that the adsorption of anions on kaolin minerals declines as $\mathrm{pH}$ of the solution increases [44]. The drop-off in adsorption of fluoride with an increase in $\mathrm{pH}$ has been explained on the root of a decrease of positive charge on the clay minerals. At minor $\mathrm{pH}$, the positively charged ion exterior on the adsorbent does not favor the sorption of anionic $\left(\mathrm{H}^{+}\right)$solution due to the repulsion of electrostatic force emerging between positively charged particles of the solution and the adsorbent surface. This is due to the maximum attraction between fluoride and adsorbent active site, and thus, the adsorbent surface is fully occupied by fluoride. At all $\mathrm{pH}$, the percentage of removal of fluoride on activated kaolin clay is greater than that on raw kaolin clay. The optimum removal of fluoride for adsorbents was found at a $\mathrm{pH}$ value of 4 . Besides, $\mathrm{pH}$ at point of zero charge (pHpzc) was obtained as 6.5. Thus, when $\mathrm{pH}$ of aqueous solution is under pHpzc, the active surface of the kaolin adsorbent becomes positively charged. However, at
$\mathrm{pH}$ above pHpzc, the surface of the adsorbent is negatively charged, and there is strong electrostatic attraction between the fluoride molecule and the surface group. On the contrary, the effects of the $\mathrm{pH}$ value on the fluoride adsorbent from aqueous solution using the kaolin adsorbent were investigated. The highest adsorption of $\mathrm{pH}$ for this material studied was obtained at $\mathrm{pH}$ 4.0. This effect can be attributed to the acid-base properties of hydroxyl groups that might be present on the adsorbent surface, and the fluoride species in solution resulted in deprotonation and protonation of the kaolin surface.

3.6.3. Effect of Particle Size. The percentages of fluoride removal with different particle sizes of the powder were premeditated. The result is present in Figure 6. The experiment was conducted by using three different particle sizes of $<0.075,0.075-0.15$, and $0.15-0.30 \mu \mathrm{m}$ at the temperature of $50^{\circ} \mathrm{C}, \mathrm{pH}$ value of 4 , and adsorbent dosage of $1 \mathrm{~g}$ for $1 \mathrm{~h}$. It has been observed that the higher percentage removal of fluoride was recorded $56.4 \%$ and $68.2 \%$ of by raw and activated kaolin clay, respectively. This is due to the availability of more surface area and void fraction on the surface of the adsorbent [45]. The adsorption process is a surface event; the fluoride removal efficiency of the sample with $0.075 \mu \mathrm{m}$ registered higher efficiency due to larger surface area and available porosity. At all particle size ranges, the percentage of removal of fluoride on activated kaolin clay is greater than that on raw kaolin clay because activation of the raw clay increases the porosity of the adsorbent by removing the impurities such as ferrous oxide, sodium, and magnesium present in the adsorbent.

3.6.4. Effect of Contact Time. To examine the minimum time required for the maximum performance of the adsorbent process, the contact time varies from 30 to $150 \mathrm{~min}$ at a minimum dose of $1 \mathrm{~g} / 100 \mathrm{~mL}, \mathrm{pH} 4$, and temperature of $50^{\circ} \mathrm{C}$ with different particle sizes $(<0.075,0.075-0.15$, and $0.1-0.30 \mathrm{~mm}$ ). From Figures $7(\mathrm{a})$ and $7(\mathrm{~b})$, it can be observed that the removal efficacy was increased with increased contact time rapidly up to $60 \mathrm{~min}$. Further increase in the contact time was not effective to improve adsorbent efficiency. However, it gradually approaches to a constant value exhibiting the fulfillment of equilibrium. The sorption reaction process indicates that it has been followed by a pattern of the two phases. The first phase was the rapid phase where the rate of removal was very rapid, and this had occurred in initial $60 \mathrm{~min}$. This may be due to the instantaneous sorption reaction in which fluoride ions were adsorbed rapidly on to the exterior of the raw and activated kaolin clay due to specific chemical interaction or affinity of the adsorbent active site and fluoride ion. After $60 \mathrm{~min}$, the rate of sorption was decreased because of minor sorption. Consequently, the movement of fluoride ions was from the boundary layer to the interior pore. From the result, a related trend was viewed for contact time and sorption efficiency of raw and activated kaolin clay. However, percentage of removal of raw clay increased from 18.6 to 54.4 for the first $60 \mathrm{~min}$ while that of activated clay increased from 42 to $68 \%$. While there was no 


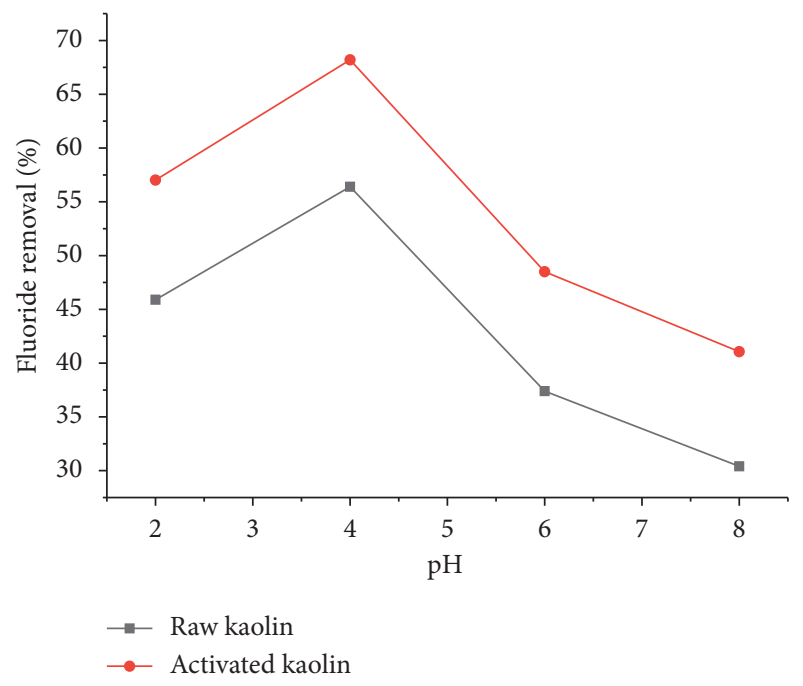

Figure 5: Effects of $\mathrm{pH}$ on fluoride removal.

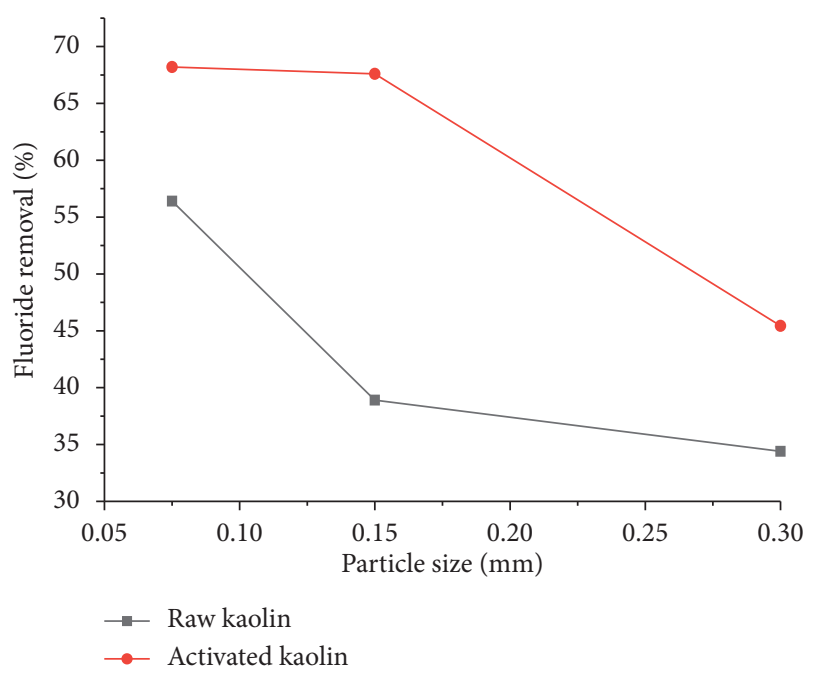

FIgURE 6: Effects of particle size on fluoride removal.

significant decrease in the percentage of removal of fluoride after $60 \mathrm{~min}$ for adsorbents, an equilibrium time of $60 \mathrm{~min}$ was taken, and this was employed in all subsequent experiments [29].

3.6.5. Effect of Dosage. The effect of adsorbent dosage on fluoride adsorption on raw and activated kaolin clay at a contact time of $60 \mathrm{~min}$, temperature of $50^{\circ} \mathrm{C}$, and $\mathrm{pH}$ value of 4 for $1 \mathrm{~h}$ was studied. The percentage of removal of both raw and activated clay particles at various dosages (0.5-2.5 g) was examined. The results are presented as percentage of fluoride removal versus adsorbent dosage in Figure 8. From Figures 8(a) and 8(b), it has been shown that the percentage of fluoride removal increases by increasing sorbent dosage from 0.5 to $2.5 \mathrm{~g}$ and stayed almost constant after $1.5 \mathrm{~g}$ of the sample in both raw clay and activated kaolin clay samples. This may be due to the configuration of stable aluminum fluoride complexes at high primary fluoride concentration. The percentage of fluoride removal increased from 23 to $61.4 \%$ for raw clay and from 35 to $74.1 \%$ for activated kaolinite clay. However, it can be observed that, after the dosage of $1.5 \mathrm{~g}$ for the adsorbent used, there was no significant alteration in the percentage of removal of fluoride due to the overlapping of active sites at higher dosage, thus reducing the net surface area. These results were inconsistent with the experimental results given by Ergun et al. [46] as a higher dosage of the adsorbent causes overlapping of active sites. In order to secure the minimum dosage adsorbent for the highest fluoride removal, testing as a function of dosage was conducted. The increase in sorption capacity with an increase in adsorbent dosage is observed since any adsorption process depends upon the number of active sites present. The same explanation holds good for the increased percent removal of activated clay than raw clay [29].

3.6.6. Adsorption Isotherm. Both Langmuir and Freundlich isotherms were used in adsorption to be aware of the level and scale of favorability of adsorption. These two most familiar isotherm models were performed in the current study to analyze equilibrium data of the solute between the adsorbent and the solution. The parameters gained from this special model afford the main information on the adsorption mechanism and the surface properties and affinities of the adsorbent. Langmuir adsorption parameters have been calculated by shifting Langmuir equation (3) into a linear form as in equation (4):

$$
\begin{aligned}
\mathrm{qe} & =\frac{\mathrm{qm} \mathrm{kLCe}}{1+\mathrm{kL} \mathrm{Ce}}, \\
\frac{1}{\mathrm{Qe}} & =\frac{1}{\mathrm{Qm}}+\frac{1}{\mathrm{Kl} \mathrm{Qm} \mathrm{Ce}} .
\end{aligned}
$$

The values of $\mathrm{qm}$ and $\mathrm{kL}$ have been computed from the intercept and slope of the Langmuir plot of 1/Qe verses 1/Ce, respectively. The correlated coefficients $\left(R^{2}\right)$ were computed from both models. The Langmuir isotherm can be stated based on a dimensionless constant called the separation factor (RL) which is defined as expressed by equation (5). The value of (RL) is tabulated in Table 2 to identify the favorability of adsorption [47].

$$
\mathbf{R L}=\frac{1}{1+\mathrm{kLCo}},
$$

where $\mathrm{kL}$ is the Langmuir constant relating to the energy of the adsorption process $(\mathrm{L} / \mathrm{mg})$ and $\mathrm{Co}$ is the highest initial fluoride concentration $(\mathrm{mg} / \mathrm{L})$. The calculated value of RL for the powder of activated clay and raw clay adsorbents was 0.35 and 0.136 , respectively. So, the value of $\mathrm{RL}$ is the range of 0 and 1 for the activated and raw clay adsorbent indicating that the equilibrium adsorption has been favorable. The applicability of the Freundlich adsorption isotherm model has been evaluated with experimental statistics. The Freundlich parameters have been determined by transforming Freundlich equation (6) into a linear form as mentioned in equation (7): 


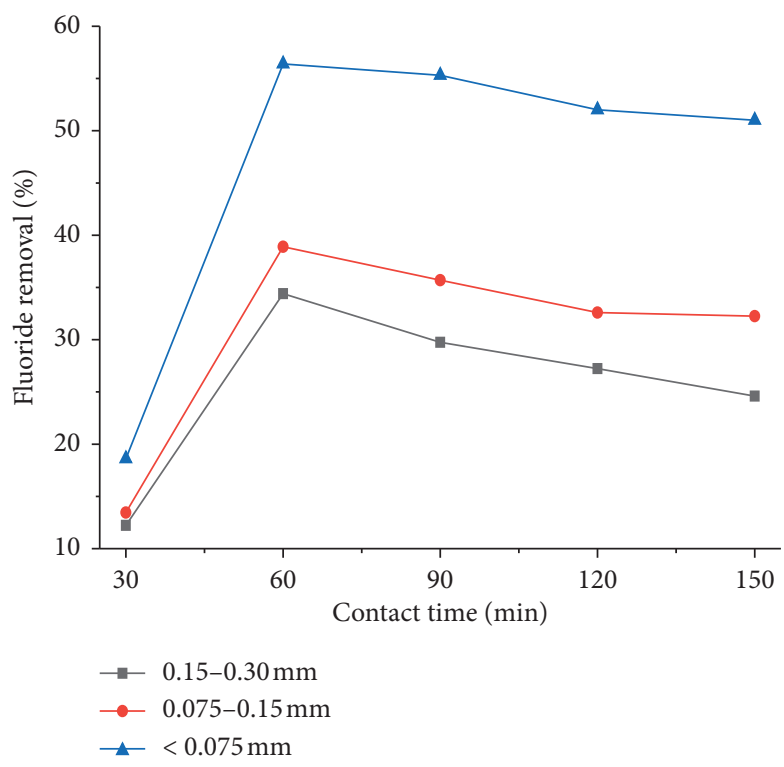

(a)

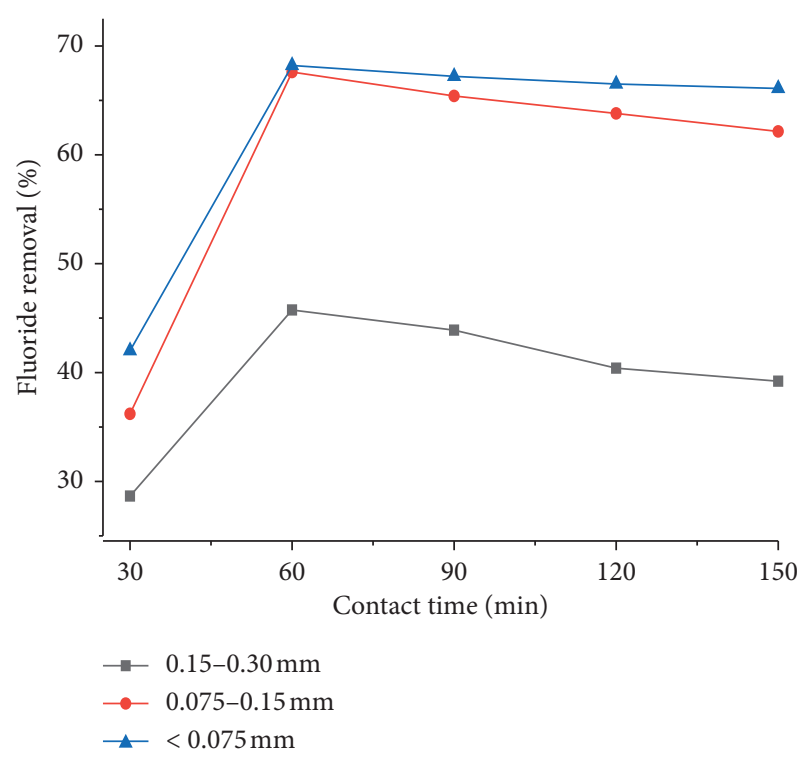

(b)

Figure 7: Effects of contact time on (a) raw clay and (b) activated clay.

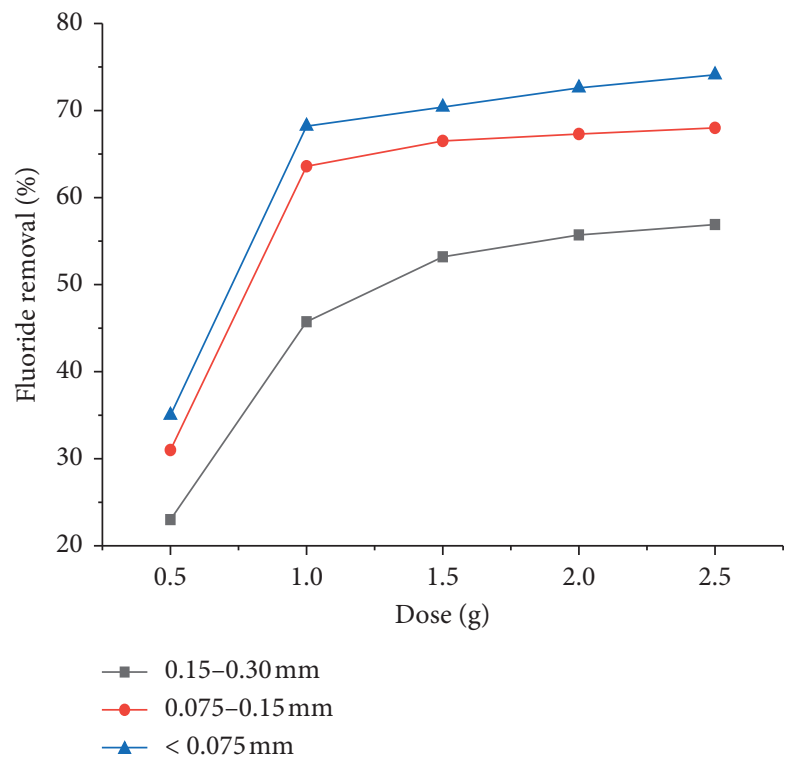

(a)

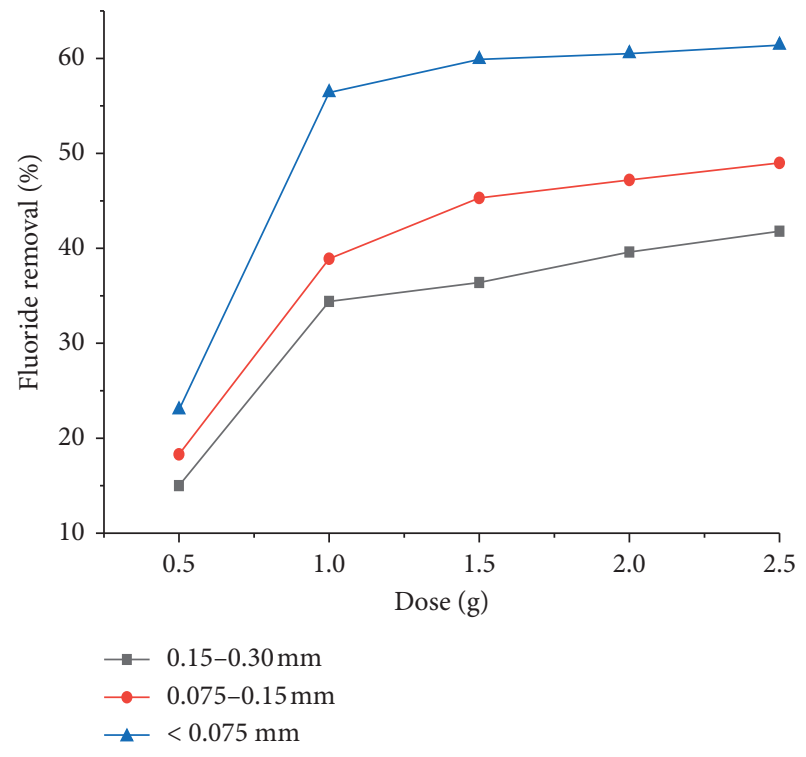

(b)

FIGURE 8: Effects of adsorbent dosage on (a) activated clay and (b) raw clay for fluoride removal.

TABLE 2: Types of the separation factor, RL of the Langmuir isotherm.

\begin{tabular}{lccc}
\hline RL value & Types of isotherm & RL obtained result \\
& & Activated clay & Raw clay \\
\hline $\mathrm{RL}>1$ & Unfavorable & - & - \\
$\mathrm{RL}=1$ & Linear & - & - \\
$0<\mathrm{RL}<1$ & Favorable & 0.35 & 0.136 \\
$\mathrm{RL}=0$ & Irreversible & - & - \\
\hline
\end{tabular}


Table 3: Langmuir and Freundlich isotherm models for adsorbents AC and RC.

\begin{tabular}{lccccc}
\hline \multirow{2}{*}{ Types of the adsorbent } & \multicolumn{3}{c}{ Langmuir isotherm parameters } & \multicolumn{3}{c}{ Freundlich isotherm parameters } \\
& $q_{m}(\mathrm{mg} / \mathrm{g})$ & $K_{L}(\mathrm{~L} / \mathrm{mg})$ & $R^{2}$ & $K_{f}(\mathrm{mg} / \mathrm{g})$ & $n$ \\
\hline Activated clay & 0.179 & 0.817 & 0.998 & 2.315 & 1.34 \\
Raw clay & 0.070 & 1.348 & 0.9906 & 1.617 & 0.999 \\
\hline
\end{tabular}

$$
\begin{aligned}
\mathbf{Q} \mathbf{e} & =\mathbf{K f}+\sqrt[n]{\mathbf{C e}} \\
\ln \mathrm{Q} \mathbf{e} & =\ln \mathbf{k f}+\left(\frac{1}{\mathbf{n}}\right) * \operatorname{lnCe} .
\end{aligned}
$$

The Langmuir and Freundlich isotherm model parameter values are presented in Table 3. The favorability of adsorption of the Freundlich isotherm model can be characterized in terms of its magnitude exponent $n$. If the value of sorption intensity $(n)$ is between 2 and 10 , it represents good, 1 to 2, quite hard, and less than 1, not good adsorption behavior [48]. In this study, the value of $n$ was 1.34 and 0.85 for activated clay and raw clay adsorbent, respectively, which showed the favorability of adsorption for activated clay is moderate and poor adsorption for raw clay.

\section{Conclusion}

This work presents a new low-cost adsorbent used for the removal of fluoride from groundwater. A series of defluoridation experiments was conducted and confirmed that the total of fluoride removal is affected by factors such as temperature, $\mathrm{pH}$, particle size, adsorbent dose, and contact time. The result of the present investigation discloses some important observations of fluoride adsorption, such as activation and calcination of an adsorbent can significantly increase the defluoridation capacity through increasing the surface area and porosity by removing volatile matter from the surface of the adsorbent. BET analysis of the clay showed that the smaller particle size that had a larger surface area was found to exhibit better removal capacity. The maximum fluoride removal was found to be $75 \%$ which occurred in $60 \mathrm{~min}$ with a fixed dose of $1 \mathrm{~g}$ activated kaolin clay. As the contact time between the adsorbate and the adsorbent increases, the rate of fluoride removal also increases up to the equilibrium point and then becomes constant, and no significant removal occurs. The adsorption process follows the Freundlich model, and the adsorption mechanism monitors the entire particle dispersion which defines the surface heterogeneity. At last, it can be concluded that the activated kaolin clay adsorbent can be used as a low-cost, effective alternative adsorbent for the removal of fluoride from groundwater. It is recommended that this economical adsorbent can be applied in an industrial scale to optimize the treatment costs of their water treatment plant.

\section{Data Availability}

All the experimental data used to support the findings of this study are included within the article. The other data are available upon request to the author.

\section{Conflicts of Interest}

The author declares that there are no conflicts of interest regarding the publication of this paper.

\section{Acknowledgments}

The author would like to thank the Faculty of Chemical and Food Engineering, Bahir Dar Institute of Technology, for providing financial support and necessary materials for the achievement of this study.

\section{References}

[1] P. D. Shankar, S. Shobana, I. Karuppusamy et al., "A review on the biosynthesis of metallic nanoparticles (gold and silver) using bio-components of microalgae: formation mechanism and applications," Enzyme and Microbial Technology, vol. 95, pp. 28-44, 2016.

[2] E. Marsili and S. K. Das, "Biosynthetic nanoparticles for biotechnological and biomedical applications," Enzyme and Microbial Technology, vol. 95, pp. 1-3, 2016.

[3] S. U. Haque, A. Nasar, A. M. Inamuddin, and A. M. Asiri, "Preparation and characterization of a bioanode (GC/MnO2/ PSS/Gph/Frt/GOx) for biofuel cell application," International Journal of Hydrogen Energy, vol. 44, no. 14, pp. 7308-7319, 2019.

[4] H. G. Baldoví, S. Neaţu, Ş. Neaţu, A. Khan, A. M. Asiri, and S. A. Kosa, "Understanding the origin of the photocatalytic $\mathrm{CO}_{2}$ reduction by $\mathrm{Au}$ - and $\mathrm{Cu}-$ loaded $\mathrm{TiO} 2$ : a microsecond transient absorption spectroscopy study," The Journal of Physical Chemistry C, vol. 119, no. 12, pp. 6819-6827, 2015.

[5] A. Khan, A. A. P. Khan, M. M. Rahman et al., "Toward facile preparation and design of mulberry-shaped poly(2-methylaniline)-Ce $\mathrm{Ce}_{2}\left(\mathrm{WO}_{4}\right) 3 @ \mathrm{CNT}$ nanocomposite and its application for electrochemical $\mathrm{Cd} 2+$ ion detection for environment remediation," Polymer-Plastics Technology and Engineering, vol. 57, no. 4, pp. 335-345, 2018.

[6] M. M. Abutalib and A. Rajeh, "Preparation and characterization of polyaniline/sodium alginate-doped $\mathrm{TiO}_{2}$ nanoparticles with promising mechanical and electrical properties and antimicrobial activity for food packaging applications," Journal of Materials Science Materials in Electron, vol. 31, pp. 9430-9442, 2020.

[7] M. T. H. Siddiqui, S. Nizamuddin, H. A. Baloch et al., "Synthesis of magnetic carbon nanocomposites by hydrothermal carbonization and pyrolysis," Environmental Chemistry Letters, vol. 16, no. 3, pp. 821-844, 2018.

[8] J. Ammann, B. Michel, and P. W. Ruch, "Characterization of transport limitations in SAPO-34 adsorbent coatings for adsorption heat pumps," International Journal of Heat and Mass Transfer, vol. 129, pp. 18-27, 2019.

[9] B. Jain, A. K. Singh, H. Kim, E. Lichtfouse, and V. k. Sharma, "Treatment of organic pollutants by homogeneous and 
heterogeneous Fenton reaction processes," Environmental Chemistry Letters, vol. 16, no. 3, pp. 947-967, 2018.

[10] A. Khan, A. A. P. Khan, M. A. Hussein, B. Neppolian, A. M. Asiri, and A. M. Asiri, "Preparation of new and novel wave like poly(2-anisidine) zirconium tungstate nanocomposite: thermal, electrical and ion-selective studies," Chinese Journal of Chemical Engineering, vol. 27, no. 2, pp. 459-466, 2019.

[11] Y. Veressinina, M. Trapido, V. Ahelik, and R. Munter, "Fluoride in drinking water:The problem and its possible solutions," Proceedings of the Estonian Academy of Sciences. Chemistry, vol. 50, pp. 81-88, 2001.

[12] WHO (World Health Organization), Guidelines for Drinking Water Quality, World Health Organization, Geneva, Switzerland, 2006.

[13] A. Meenakshi and R. C. Maheshwari, "Fluoride in drinking water and its removal," Journal of Hazardous Materials, vol. 137, no. 1, pp. 456-463, 2006.

[14] C. Reimann, K. Bjorvatn, B. Frengstad, Z. Melaku, R. TekleHaimanot, and U. Siewers, "Drinking water quality in the Ethiopian section of the East African Rift Valley I-data and health aspects," Science of the Total Environment, vol. 311, no. 1-3, pp. 65-80, 2003.

[15] M. A. Zenasni, S. Benfarhi, A. Merlin, S. Molina, B. George, and B. Meroufel, "Adsorption of nickel in aqueous solution onto natural maghnite," Materials Sciences and Applications, vol. 4, no. 2, pp. 153-161, 2013.

[16] Federal Democratic Republic of Ethiopia, Ethiopian Quality and Standard Authority Guidelines for Drinking Water Quality, Federal Democratic Republic of Ethiopia, Addis Ababa, Ethiopia, 2001.

[17] Federal Democratic Republic of Ethiopia, Ministry of Water Resources, Ethiopia Guidelines Specification for Drinking Water Quality, Federal Democratic Republic of Ethiopia, Addis Ababa, Ethiopia, 2002.

[18] S. De Gisi, G. Lofrano, M. Grassi, and M. Notarnicola, "Characteristics and adsorption capacities of low-cost sorbents for wastewater treatment: a review," Sustainable Materials and Technologies, vol. 9, pp. 10-40, 2016.

[19] E. J. Reardon and Y. Wang, "A limestone reactor for fluoride removal from wastewaters," Environmental Science \& Technology, vol. 34, no. 15, pp. 3247-3253, 2000.

[20] M. S. Onyango and H. Matsuda, "Chapter 1 fluoride removal from water using adsorption technique," Advances in Fluorine Science, vol. 2, pp. 1-48, 2006.

[21] G. Alagumuthu, V. Veeraputhiran, and R. Venkataraman, "Adsorption isotherms on fluoride removal: Batch techniques," Scholars Research Library, vol. 2, pp. 170-185, 2010.

[22] S. Ghorai, K. K. Pant, and K. K. Pant, "Equilibrium, kinetics and breakthrough studies for adsorption of fluoride on activated alumina," Separation and Purification Technology, vol. 42, no. 3, pp. 265-271, 2005.

[23] W. Nigussie, F. Zewge, and B. S. Chandravanshi, "Removal of excess fluoride from water using waste residue from alum manufacturing process," Journal of Hazardous Materials, vol. 147, pp. 954-963, 2007.

[24] M. S. Onyango, T. Y. Leswifi, A. Ochieng, D. Kuchar, F. O. Otieno, and H. Matsuda, "Breakthrough analysis for water defluoridation using surface-tailored zeolite in a fixed bed column," Industrial \& Engineering Chemistry Research, vol. 48, no. 2, pp. 931-937, 2009.

[25] K. Vaaramaa and J. Lehto, "Removal of metals and anions from drinking water by ion exchange," Desalination, vol. 155, no. 2, pp. 157-170, 2003.
[26] O. A. Obijole, M. W. Gitari, and P. G. Ndungu, "Mechanochemically activated Aluminosilicate clay soils and their application for defluoridation and pathogen removal from groundwater," International Journal of Environmental Research and Public Health, vol. 16, p. 254, 2019.

[27] R. S. Sathish, N. S. R. Raju, G. S. Raju, G. Nageswara Rao, K. A. Kumar, and C. Janardhana, "Equilibrium and kinetic studies for fluoride adsorption from water on zirconium impregnated coconut shell carbon," Separation Science and Technology, vol. 42, no. 4, pp. 769-788, 2007.

[28] P. P. Coetzee, L. L. Coetzee, R. Puka, and S. Mubenga, "Characterization of selected South African clays for defluoridation of natural waters," Water SA, vol. 29, pp. 331-338, 2003.

[29] S. Meenakshi, S. Sairam, C. S. Sundaram, and R. Sukumar, "Enhanced fluoride sorption by mechanochemically activated kaolinites," Journal of Hazardous Materials, vol. 153, no. 1-2, pp. 164-172, 2008.

[30] G. Priya, S. Ashok, S. Sarita, and V. Sanjay, "Defluoridation of water using low cost adsorbent," International Journal of Chemical Studies, vol. 3, pp. 109-112, 2015.

[31] A. A. Adeyi, T. G. Abayomi, M. K. Purkait, and P. Mondal, "Adsorptive removal of phosphate from aqueous solution by magnetic-supported kaolinite: characteristics, isotherm and kinetic Studies," Open Journal of Applied Sciences, vol. 9, no. 7, pp. 544-563, 2019.

[32] G. P. Kofa, V. H. Gomdje, C. Telegang, and S. N. Koungou, "Removal of fluoride from water by adsorption onto fired clay pots: kinetics and equilibrium studies," Journal of Applied Chemistry, vol. 2017, pp. 1-7, 2017.

[33] Y. Çengeloglu, E. Kır, and M. Ersoz, "Removal of fluoride from aqueous solution by using red mud," Separation and Purification Technology, vol. 28, no. 1, pp. 81-86, 2002.

[34] G. Karthikeyana, A. Piusa, and G. Alagumuthu, "Fluoride adsorption studies of montmorillonite clay," Indian Journal of Chemical Technology, vol. 12, pp. 263-272, 2005.

[35] G. Crini, "Non-conventional low-cost adsorbents for dye removal: a review," Bioresource Technology, vol. 97, no. 9, pp. 1061-1085, 2006.

[36] S. Mann and A. Mandal, "Removal of fluoride from drinking water using sawdust," International Journal of Engineering Research and Applications, vol. 4, pp. 116-123, 2014.

[37] F. Bergaya and G. Lagaly, "General introduction," Developments in Clay Science, vol. 5, pp. 1-19, 2013.

[38] K. Gomoro, F. Zewge, B. Hundhammer, and N. Megersa, "Fluoride removal by adsorption on thermally treated lateritic soils," Chemical Society of Ethiopia, vol. 26, pp. 361-372, 2012.

[39] K. B. Sailaja, D. Bhagawan, V. Himabindu, and C. Jyostna, "Removal of fluoride from drinking water by adsorption onto activated alumina and activated carbon," International Journal of Engineering Research and Applications, vol. 5, pp. 19-24, 2015.

[40] Z. Barghouthi and S. Amereih, "Spectrophotometric determination of fluoride in drinking water using aluminum complexes of triphenylmethane dyes," Water SA, vol. 38, pp. 543-548, 2012.

[41] N. Nasuha, B. H. Hameed, and A. T. M. Din, "Rejected tea as a potential low-cost adsorbent for the removal of methylene blue," Journal of Hazardous Materials, vol. 175, no. 1-3, pp. 126-132, 2010.

[42] S. Janta, S. Watanesk, R. Watanesk, and S. Thiensem, "Cost effective natural adsorbent for fluoride removal," Advanced Materials Research, vol. 57, pp. 865-868, 2008. 
[43] R. Srinivasan, "Advances in application of natural clay and its composites in removal of biological, organic, and inorganic contaminants from drinking water," Advances in Materials Science and Engineering, vol. 2011, Article ID 872531, 17 pages, 2011.

[44] M. Mohapatra, S. Anand, B. K. Mishra, D. E. Giles, and P. Singh, "Review of fluoride removal from drinking water," Journal of Environmental Management, vol. 91, no. 1, pp. 67-77, 2009.

[45] A. Maiti, J. K. Basu, and S De, "Chemical treated laterite as promising fluoride adsorbent for aqueous system and kinetic modeling," Desalination, vol. 265, no. 1-3, pp. 28-36, 2011.

[46] E. Ergun, A. Tor, Y. Cengeloglu, and I. Kocak, "Electrodialytic removal of fluoride from water: effects of process parameters and accompanying anions," Separation and Purification Technology, vol. 64, no. 2, pp. 147-153, 2008.

[47] E. Togarepi, C. Mahamadi, and A. Mangombe, "Deflouridation of water using physico-chemically treated sand as a low-cost adsorbent: an equilibrium study," African Journal of Environmental Science and Technology, vol. 6, no. 3, pp. 176-181, 2012.

[48] A. Vinati, B. Mahanty, and S. K. Behera, "Clay and clay minerals for fluoride removal from water: a state-of-the-art review," Applied Clay Science, vol. 114, pp. 340-348, 2015. 